\title{
STUDYING THE EFFECT OF BENZOPHENONE ON THERMAL DEGRADATION OF CELLULOSE DIACETATE
}

\author{
Hammed Hashem Mohamed \\ Department of Chemistry, College of Science, Al-Mustansiriya University, \\ Baghdad-Iraq.
}

\begin{abstract}
The induced thermal degradation of cellulose diacetate (CDA) was investigated in the absence and presence of benzophenone (BPH).

CDA are prepared in the laboratory from filter paper, which is characterizated by spectrophotometry (infrared and ultraviolet visible) techniques in addition to the determination of the degree of substitution.

The addition of $(0.5 \mathrm{wt} \%)$ of benzophenone to cellulose diacetate enhanced the thermal degradation of the polymer.

Themal degradation rate was measured by ultraviolet visible spectra, decreasing in viscosity and reduction of molecular weight were also observed in the degraded samples. Changes in the numberaverage chain scission and the degree of deterioration. Which were evaluated by analytical techniques indicated that the benzophenone enhance the thermal degradation of cellulose diacetate .
\end{abstract}

\section{Introduction}

When a polymer blend is degraded thermally, it is often found that the behavior of polymer is modified $^{(1-4)}$. The thermal degradation of pure cellulose acetate and cellulose acetate with mono ammonium phosphate and boric acid as physically incorporated additives, was investigated using thermogravimetry analysis, thermal volatilization analysis and characterization of the degradation products by infrared spectroscopy. The additives modified the degradation process by decreasing the thermal stability of the polymer, enhancing the char and reducing the volatile formation. The addition of ammonium phosphate and boric acid together showed a synergistic effect in increasing char quantity. In this case a decrease in thermal stability was not observed. The analysis of degradation products showed that the cellulose acetate decomposition occurred by scission of glycosidic linkages followed by pyranose ring rupture and acetic acid evolution. Kinetic parameters, like activation energy, were calculated following the Ozawa method using dynamic thermogravimetric data ${ }^{(5)}$. The thermal degradation of cellulose, cellulose phosphates, and cellulose thiophosphates was studied by differential thermal analysis, dynamic thermogravimetry, and derivative thermogravimetry from ambient temperature up to $750^{\circ} \mathrm{C}$. Various thermodynamic parameters for different stages of thermal degradation of cellulose and its derivatives have been obtained following the methods of Broido, and Freeman and Carroll. Infrared spectra of thermally degraded samples were obtained. The data were analyzed in an effort to obtain more information concerning the flame-retardant mechanisms of cellulose phosphates and cellulose thiophosphates. Lower values of decomposition temperatures and activation energies of decomposition and higher char yields of cellulose phosphates as compared to cellulose lead to the conclusion that cellulose phosphorus esters are good flame retardants ${ }^{(6)}$.

\section{Experimental}

\section{1- Materials}

\section{A- Preparation of cellulose diacetate}

In a conical flask, filter paper (5 g) was added to acetic anhydride $(15 \mathrm{ml})$, then glacial acetic acid $(25 \mathrm{ml})$ and conc. $\mathrm{H}_{2} \mathrm{SO}_{4}(0.7 \mathrm{ml})$ were added slowly with continuous stirring. Stirring was continued for $24 \mathrm{hr}$ at $50-60^{\circ} \mathrm{C}$. solution of $\left(\mathrm{H}_{2} \mathrm{O}\right.$-acetic acid) $(32.5-30 \mathrm{ml})$ was added to the mixture with stirring for 15 minutes. The mixture was poured onto cooled water $(300 \mathrm{ml})$ to give white precipitate which was filtered, washed with distilled water 
and ethanol, then precipitate was dried at $60{ }^{\circ} \mathrm{C}$ to give pure cellulose diacetate (degree of substitution is 2.79-2.82).

\section{B- Benzophenone (BPH) ${ }^{[7]}$}

Laboratory benzophenone (B.D.H. Ltd A.R.Grade) was recrystallized from methanol, then dried in air at room temperature.

\section{2-Determination Degree of Substitution (D.S)}

Degree of substitution (D.S) of cellulose diacetate was determined by the following relation:

$$
\text { D.S }=\frac{162 \times \mathrm{Ac} \%}{100 \mathrm{w}-\mathrm{w}_{1} \mathrm{Ac} \%}
$$

Where :

W: formula weight for acetic acid

$\mathrm{W}_{1}$ : represents increasing in weight of cellulose formula produced from addition one substitution on one anhydroglucose which is equal 162.

Ac: represents percentage of acetic acid

About ( $1 \mathrm{~g})$ of the sample is dried in a weighing bottle at $(105 \pm 3){ }^{\circ} \mathrm{C}$ for $2 \mathrm{hr}$. stopper, and cooled in a deseicator. The sample is transferred to a $250 \mathrm{ml}$ Erlenmeyer flask, and $40 \mathrm{ml}$ of ethyl alcohol (75\%) is added to sample and the blank. The flask is heated for $30 \mathrm{~min}$. at 50 to $60{ }^{\circ} \mathrm{C}$. Then $40 \mathrm{ml}$ of $0.5 \mathrm{~N} \mathrm{NaOH}$ solution is added to each flask and heated again at 50 to $60{ }^{\circ} \mathrm{C}$ for $15 \mathrm{~min}$. The flasks are tightly stoppered and allowed to stand at room temperature for about (48-72)hr. At the end of this, back-titration of the excess of $\mathrm{NaOH}$ with $0.5 \mathrm{~N} \mathrm{HCl}$ is done, using phenolphthalein as indicator An excess of about $1 \mathrm{ml}$ of $0.5 \mathrm{~N} \mathrm{HCl}$ is added and allow the $\mathrm{NaOH}$ to diffuse from the regenerated cellulose for several hours, or preferably overnight, then the following relations is used to determine the percentage of combined acetyl or acetic acid as follows:

$$
\begin{aligned}
\text { Acetyl or acetic acid } \%= & {\left[(\mathrm{D}-\mathrm{C}) \mathrm{N}_{\mathrm{a}^{-}}\right.} \\
& \left.(\mathrm{A}-\mathrm{B}) \mathrm{N}_{\mathrm{b}}\right] \mathrm{F} / \mathrm{W}
\end{aligned}
$$

Where

A: milliliters of $\mathrm{NaOH}$ solution required for titration of the sample.

B: milliliters of $\mathrm{NaOH}$ solution required for titration of the blank.

$\mathrm{N}_{\mathrm{b}}$ : normality of the $\mathrm{NaOH}$ solution.
C: milliliters of $\mathrm{HCl}$ required for titration of the sample.

D: milliliters of $\mathrm{HCl}$ required for titration of blank.

$\mathrm{N}_{\mathrm{a}}$ : normality of the $\mathrm{HCl}$ solution.

F : 4.305 for acetyl or 6.005 for acetic acid.

$\mathrm{W}$ : grams of polymeric sample used.

\section{3-Thermal degradation method}

Cellulose diacetate $(0.2 \mathrm{~g})$ and benzophenone $(0.005 \mathrm{~g})$ were dissolved in dimethylformamide $(10 \mathrm{ml})$ and introduced in a $20 \mathrm{ml}$ sealed tube under argon gas. The mixture was heated at $120{ }^{\circ} \mathrm{C}$ for $1-5 \mathrm{hr}$ on an oil bath.

\section{4-Determination of Viscosity Average Molecular Weight $\left(\mathrm{M}_{\mathrm{v}}\right)$ Using Viscometry method}

The viscosity property was used to determine the viscosity average molecular weight of the polymers using Mark -Houwink relation $^{[8]}$

$$
[\eta]=K\left(\bar{M}_{v}\right)^{\alpha}
$$

where,

$[\eta]=$ intrinsic viscosity

$\mathrm{K}$ and $\alpha$ : are constants for a given polymer at a given temperature in a given solvent.

The intrinsic viscosity of a polymer solution was measured with an Ostwald U-tube viscometer .Solutions were made by dissolving the polymer in acetone solvent $(\mathrm{g} / 100 \mathrm{~m})$ at $\left(25 \mathrm{C}^{\circ}\right)$ temperature and the flow times of polymer solution $(\mathrm{t})$ and pure acetone solvent $\left(t_{\circ}\right)$, were measured respectively. The relative viscosity $\left(\eta_{\text {rel }}\right)$ which is given by the ratio of the flow time for the solution ( $t$ ) to the flow time of the pure solvent $\left(t_{0}\right)$ was calculated from equation (4).

$$
\eta_{\text {rel }}=\frac{\mathrm{t}}{\mathrm{t}}
$$

The specific viscosity $\left(\eta_{\mathrm{sp}}\right)$, which is the relative increment in viscosity of the solution over the viscosity of the solvent is :

$$
\eta_{\mathrm{sp}}=\left(\eta-\eta_{\mathrm{o}}\right) / \eta_{\mathrm{o}}=\eta_{\text {rel }}-1
$$

The intrinsic viscosity $([\eta])$ is the limiting viscosity number or (the reduced specific viscosity), was calculated using Huggins relation $^{[12]}$. 


$$
|\eta|=\left[(\sqrt{2} / \mathrm{C})\left(\eta_{\mathrm{sp}}-\ln \eta_{\mathrm{rel}}\right)\right]^{1 / 2}
$$

Where,

$\mathrm{C}=$ concentration of polymer solution $(\mathrm{g} / 100 \mathrm{~mL})$. The viscosity average molecular weight of degraded and undegraded polymer can be calculated by applying equation (3).

The average number of main chain scission (s) and degree of degradation ( $\alpha$ ) were calculated as follows:

$$
\begin{aligned}
& S=\frac{\bar{M}_{v}}{\bar{M}_{v}}-1 \\
& \alpha=\frac{m}{\bar{M}_{v_{0}}} S .
\end{aligned}
$$

where,

$\overline{\mathrm{M}}_{\mathrm{v}}$, and $\overline{\mathrm{M}}_{v}$, are the viscosity average molecular weights before and after thermal degradation.

$\mathrm{m}=$ molecular weight of monomer.

\section{5-Ultraviolet Visible Spectrophotometry (U.V)}

The absorption spectra was recorded using the ultraviolet visible spectrophotometer type (Hitachi U-2000), in the wavelength range between 200 to $800 \mathrm{~nm}$.

\section{Results and Discussion}

\section{1-Molecular weight change during thermal degradation}

In order to clarify the thermal mechanisms of CDA solution, the ultraviolet spectrum has to be investigated. Thermal reactions involve both physical and chemical processes. The last possibility involves chemical processes which may include decomposition, depolymerization, and atomic abstraction reaction. Most of these involve free radical intermediates.

Thermal degradation of cellulose acetate is exactly of the same processes that occur in any photochemical reaction. The ultraviolet absorption spectrum of CDA solution without any additive is shown in Fig.(1), the CDA begin to absorb strongly below wavelength $\lambda=300 \mathrm{~nm}$, it is obvious that while saccharide is transparent till wavelength $210 \mathrm{~nm}$, this absorption has probably attributed to the free reducing sugar groups. As shown in Fig.(1) absorption in the wavelength 200 to $300 \mathrm{~nm}$ range is decreased after thermal degradation reaction.
The changes in UV-Visible spectra for CDA solution with BPH are observed in Figs.(2). From the results obtained in this figure, one can be observed that the absorbance in the wavelength300-400 nm range increases with degradation time due to formation ketonic compounds.

One can expect that ketones, can cleavage into free radicals. These radicals may initiate polymer degradation and other transformations by abstraction of hydrogen atom from a macromolecule $(\mathrm{PH})$ and formation of polymer alkyl radical. To provide indication of thermal degradation, viscosity measurement was made on solutions of selected CDA solution to determine changes in molecular weight.

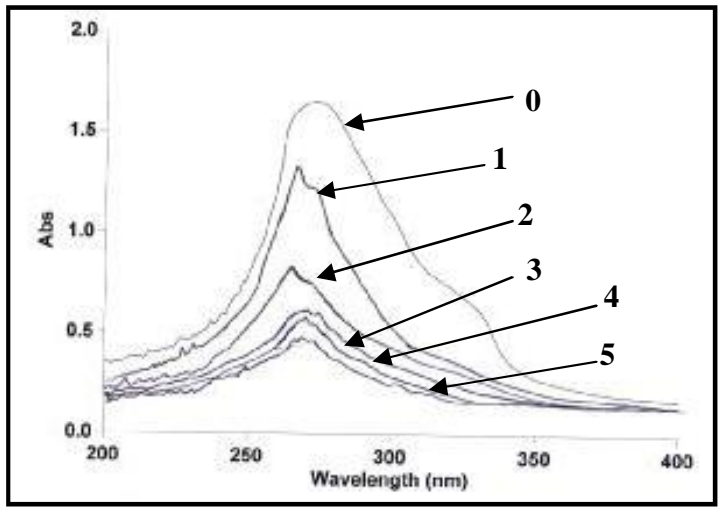

Fig.(1) : U.V. -visible spectral change of CDA (control). Numbers on the spectra are thermal times in hours.

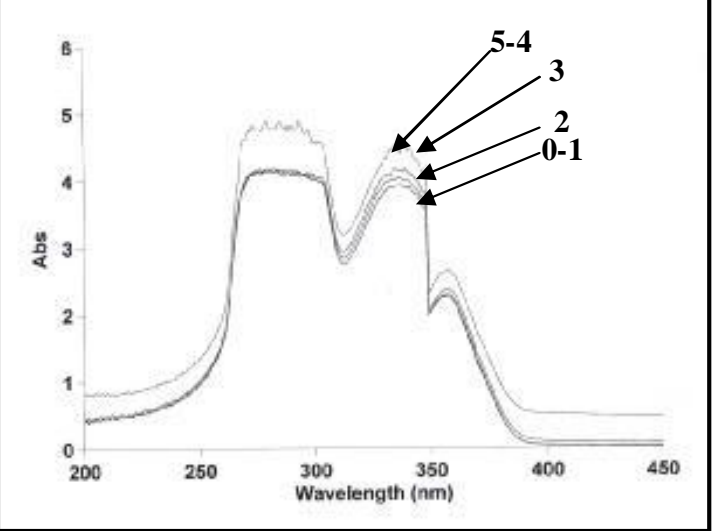

Fig. (2) : U.V. -visible spectral change of $B P H$ in CDA.Numbers on the spectra are thermal times in hours. 
Furthermore, the molecular weight loss additive than CDA polymer (control). was greater for CDA polymer containing BPH

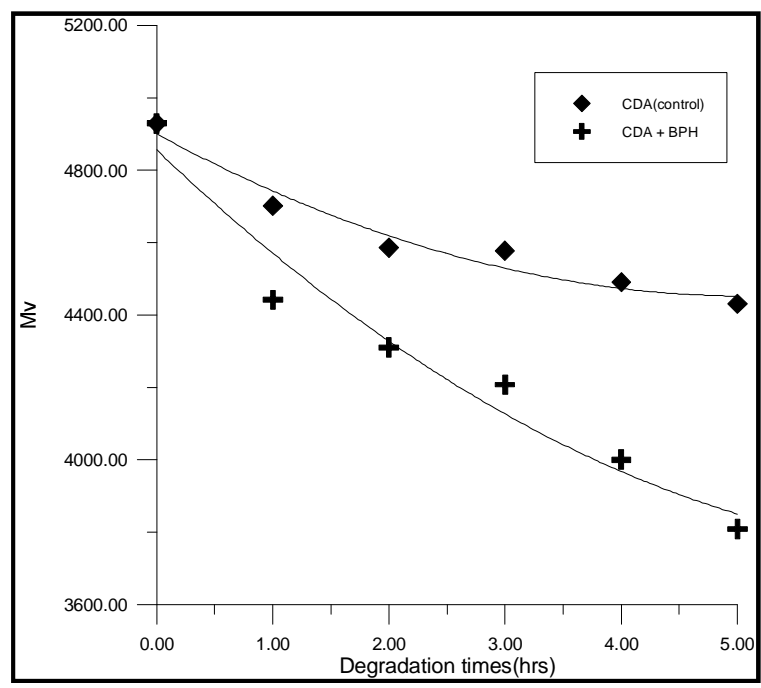

Fig.(3) : Changes in the viscosity average molecular weight during thermal degradation of CDA films (control)and with (0.5wt\%) of additive.

Table (1)

The variation of $\alpha, S, P t, d M_{v} / d t,\left(M_{v}\right)^{2}$ and $M_{v}$ with thermal time on cellulose diacetate containing $(0.5 \% \mathrm{wt})$ additive.

\begin{tabular}{|c|c|c|c|c|c|c|c|c|}
\hline $\begin{array}{l}\text { Additives } \\
\text { concentration } \\
0.5 \%(\mathbf{W t} / \mathbf{W t})\end{array}$ & $\begin{array}{l}\text { Thermal } \\
\text { time (hrs) }\end{array}$ & $\begin{array}{c}\overline{M_{v}} \\
(g / m l)\end{array}$ & $\begin{array}{c}\left(\overline{\mathrm{M}_{\mathrm{v}}}\right)^{2} \times 10^{4} \\
(\mathrm{~g} / \mathrm{ml})\end{array}$ & $\mathrm{d} \overline{\mathrm{M}_{\mathrm{v}}} / \mathbf{d t}$ & $\mathbf{P}_{\mathbf{t}}$ & $1 / \mathbf{P}_{t}$ & $\alpha$ & $\mathbf{S}$ \\
\hline \multirow{6}{*}{ CDA } & 0 & 4930 & 2430 & - & 18.674 & 0.053 & - & - \\
\hline & 1 & 4701 & 2209 & 229 & 17.80 & 0.056 & 0.002 & 0.048 \\
\hline & 2 & 4586 & 2103 & 172 & 17.37 & 0.0576 & 0.0040 & 0.074 \\
\hline & 3 & 4578 & 2095 & 117.3 & 17.34 & 0.0577 & 0.0041 & 0.076 \\
\hline & 4 & 4490 & 2016 & 110 & 17.01 & 0.0590 & 0.0054 & 0.100 \\
\hline & 5 & 4430 & 1962 & 100 & 16.78 & 0.0596 & 0.006 & 0.112 \\
\hline \multirow{6}{*}{$\mathrm{CDA}+\mathrm{BPH}$} & 0 & 4930 & 2430 & & 12.293 & 0.077 & - & - \\
\hline & 1 & 4442 & 1973 & 488 & 16.826 & 0.059 & 0.008 & 0.220 \\
\hline & 2 & 4310 & 1857 & 310 & 16.326 & 0.061 & 0.011 & 0.1968 \\
\hline & 3 & 4208 & 1770 & 240.66 & 15.939 & 0.062 & 0.014 & 0.179 \\
\hline & 4 & 4000 & 1600 & 232.5 & 15.151 & 0.066 & 0.016 & 0.139 \\
\hline & 5 & 3808 & 1450 & 224.4 & 14.424 & 0.069 & 0.017 & 0.098 \\
\hline
\end{tabular}


Table (1) and Fig.(3), show a rapid decrease in $\overline{\mathrm{M}_{\mathrm{v}}}$ initially which then slow down, for the CDA solution (control) and with additive, suggesting that the initial rapid decrease in $\overline{\mathrm{M}}_{\mathrm{v}}$ is due to scission of bonds at various weak links which distributed along the polymer chain. The thermal degradation process becomes slower and the bonds scission may be random.

For randomly distributed weak links which break rapidly in the initial stages, the degree of degradation $\alpha$ is a function of thermal time is shown in Fig.(4).

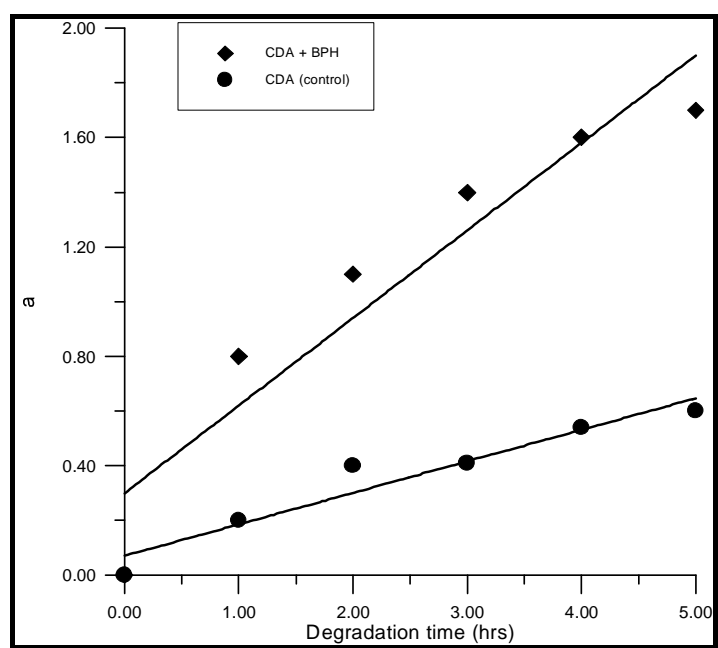

Fig.(4): Change in the degree of deterioration ( $\alpha$ ) during thermal degradatio of CDA films (control) and with (0.5 wt\%)of additives.

The curves are linear proving that the degradation is taking place by random breaking of one type of bond.As shown in Fig.(4), the $(\alpha)$ values of degraded samples are higher with $\mathrm{BPH}$ as compared to the corresponding values of CDA solution (control). The values of $(\alpha)$ increase rapidly with degraded time, which indicates to random breaking of bonds in the polymer chain.

The plots of (S) as a function of time is shown in Fig.(5). The linearity of the plots of (S) versus degraded time gives an indication that no increase in the degree of branching which might arise from cross linking occur in CDA with and without BPH additive.

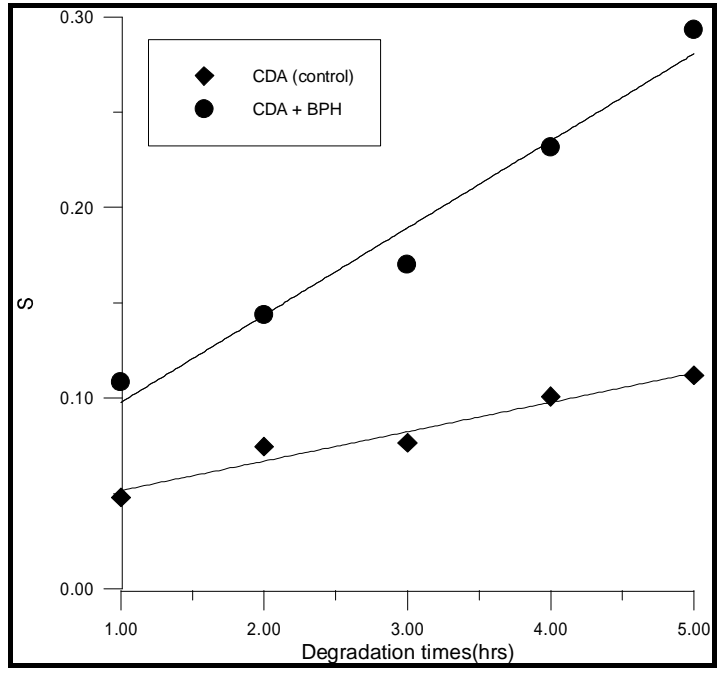

Fig. (5): Changes in the number-average chain scission (S) for CDA (control) and with (0.5 wt\%)of additive.

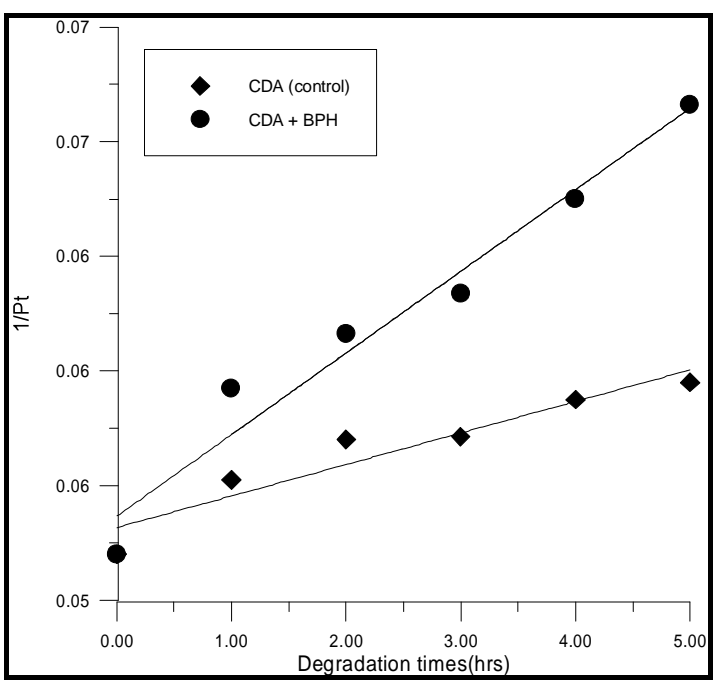

Fig.(6) : Change in the reciprocal value of number-average degree of polymerization during thermal degraded of CDA (control) and with $(0.5 w t \%)$ of additive.

\section{2-The mechanism of thermal degradation}

Most types of degradation follow a similar basic pattern. The conventional model for thermal degradation is that of an autoxidation process which involves the major steps of initiation, propagation, branching, and termination.

\section{i-Initiation}

The initiation of thermal degradation involves the loss of a hydrogen atom from the polymer chain as a result of energy input from 
heat or light. This creates a highly reactive and unstable polymer 'free radical' $\left(\mathrm{P}^{*}\right)$ and a hydrogen atom with an unpaired electron $\left(\mathrm{H}^{*}\right)$.

$$
\mathrm{PH} \stackrel{h v}{\longrightarrow} P^{\bullet}+H^{\bullet} \text {. }
$$

\section{ii-Propagation}

The propagation of thermal degradation can involve a variety of reactions and one of these is where the free radical $\left(\mathrm{P}^{*}\right)$ reacts with an oxygen $\left(\mathrm{O}_{2}\right)$ molecule to form a peroxy radical (POO*) which can then remove a hydrogen atom from another polymer chain to form a hydroperoxide (POOH) and so regenerate the free radical $\left(\mathrm{P}^{*}\right)$. The hydroperoxide can then split into two new free radicals, $\left(\mathrm{PO}^{*}\right)+\left({ }^{*} \mathrm{OH}\right)$, which will continue to propagate the reaction to other polymer molecules. The process can therefore accelerate depending on how easy it is to remove the hydrogen from the polymer chain.

$$
\begin{aligned}
& \mathrm{P}^{\circ}+\mathrm{O}_{2} \rightarrow \mathrm{POO}^{\circ} \\
& \mathrm{POO}^{\circ}+\mathrm{P}^{\prime} \mathrm{H} \rightarrow \mathrm{POOH}+\mathrm{P}^{\circ} . \\
& \mathrm{POOH} \rightarrow \mathrm{PO}^{\circ}+{ }^{\circ} \mathrm{OH}
\end{aligned}
$$

\section{iii-Termination}

The termination of thermal degradation is achieved by 'mopping up' the free radicals to create inert products. This can occur naturally by combining free radicals or it can be assisted by using stabilizers in the plastic.

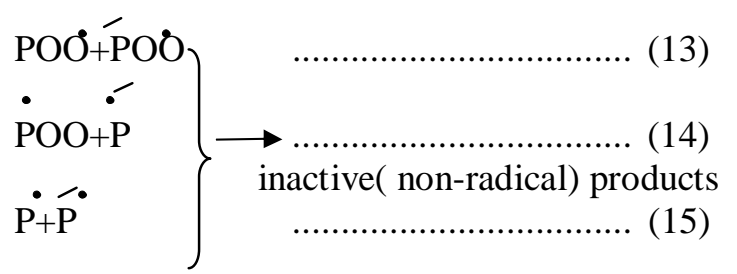

In some polymers it is also possible to get 'branching' of the polymer chains, this is where two polymer chains become linked together and results in cross-linking and embitterment of the polymer.

A number of different thermal degradation reactions are known to occur with cellulose at different temperatures. Degradation at lower temperatures (as in aging of cellulosic materials) is often predominantly thermooxidative and/or hydrolytic. As expected, aging of cellulose is, thus, usually a function of humidity, light, oxygen availability, etc., in addition to temperature. At higher temperatures $\left(>200{ }^{\circ} \mathrm{C}\right.$ ) water is lost, first from that absorbed by the cellulose and then by $\beta$-elimination from the cellulose hydroxyls. At still higher temperatures $\left(>250{ }^{\circ} \mathrm{C}\right)$, several competing pyrolytic reactions begin to take over. These reactions can be grouped into three basic classifications: the first group occurs at lower temperatures and is similar to the aging reactions. Products are water, $\mathrm{CO}$, $\mathrm{CO}_{2}$ and a carbonaceous char. At higher temperatures, another reaction begins to take over which results in depolymerization of the cellulose chain and formation of anhydroglucose derivatives, volatile organic materials and tars. At still higher temperatures, more-or-less random bond cleavage of cellulose and intermediate decomposition products results in formation of a variety of low molecular weight compounds.

\section{Conclusion}

It is concluded from the present study that for thermal degradation of cellulose diacetate film under high temperature conditions and using benzophenone as sensitizer high degraded than cellulose diacetate control.

\section{References}

[1] G.Silvalingam, R.Karthik and G.Madras, Ind. Eng. Chem.. Res., 42,3647 (2003).

[2] M.Rogestedt and T.Hjertberg, Polym. Degrade Stab., 45,19 (1994).

[3] I.C.Mcniell, and S.Basan, Polym. Degrade Stab., $\underline{39}, 145$ (1993).

[4] D.F.Varnell, J.P.Runt and M.M.Coleman, Polymer, 24,37 (1983).

[5] M.Da.C.C.Lucena, A.E.V.De Alencar, S.E.Mazzeto and S.De.A.Soares, "The effect of additives on the thermal degradation of cellulose acetate", Polym. Degrade Stab., 80, 149 (2003).

[6] K.Baljinder, S.G.Ishwar and H. L. Bhatnagar, "Thermal degradation studies of cellulose phosphates and cellulose thiophosphtes", Macromolecular Materials and Engineering, 147, 157 (2003).

[7] W. L. F. Armarego and D. D. Perrin, "Purification of Laboratory Chemicals", Fourth Edition,pp.95, (1998).

[8] R.Houwink, J.Prakt,Chem.,157,15,(1940). 
تضمن هذا البحث دراسة التجزئة الحراريـــة المحتثــة

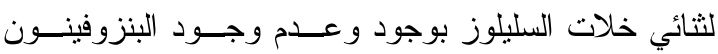
benzophenone (BPH) حمام زيتي بدرجة حرارة 150 م، لقد تم تحــضير لثتـائي خلات السليلوز من ورق الترشـيح. و شخـصت المــادة البوليميرية المحضرة بواسطة الطــرق الطيفيـة (اطيـاف الاشعة تحت الحمراء و اطياف الاشــعة فــوق البنفـسجية و المرئية) اضافة الى تحديد درجة التعويض لهم (D.S).

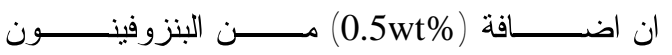
benzophenone (BPH) يزيد التجزئة الحرارية للبوليمر . تم قياس التجزئة الحراريــة من خلال متابعة التغير في اطياف الاشعة فوق البنفـسجية و المرئية كما تم ملاحظة النقصان فـي اللزوجــة و الـــوزن الجزيئي من خلال متابعة التغير في المعدل العــددي لقطــع السلسلة ودرجة التجزئة وقد اظهـرت نتــائج التحليـلـل ان

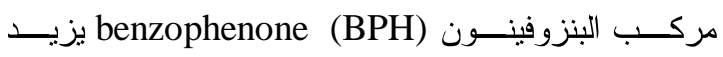
التجزئة الحر ارية لثنائي خلات السليلوز . 